\title{
CSR Monetary Accounting Impact Mechanism: A Conceptual Model
}

\author{
Dr. Mona Abou Taleb (Corresponding author) \\ Lecturer, Environmental Accounting Department \\ Center of Environmental Planning and Development \\ Institute of National Planning, Nasr City, Cairo, Egypt \\ E-mail: mona-inp@hotmail.com
}

Received: November 27, 2016 Accepted: December 21, 2016 Published: January 02, 2017

doi:10.5296/ijafr.v6i2.11002 URL: http://dx.doi.org/10.5296/ijafr.v6i2. 11002

\begin{abstract}
Companies adopt non-comprehensive accounting approaches to optimise their decisionmaking and reporting using mainly quantitative CSR impacts with less emphasis on monetising qualitative descriptive and physical impacts, despite those aspects being of significant concern to stakeholders. Thus, the study is motivated by the need for current sustainability accounting practice to develop a model that incorporates a full range of CSRdecision drivers; financial, environmental, social in addition to involving corporate governance drivers for the first time in the literature into decision-making and accounting systems to develop a comprehensive monetary accounting mechanism. Based on the theoretical and conceptual analyses, the CSR monetary accounting impact mechanism model is developed to provide sustainable accounting practices with comprehensive monetary measurement for stakeholders and organisations.
\end{abstract}

Keywords: Corporate social responsibility (CSR); Stakeholder engagement; Stakeholder theory; Prospect decision theory; Global reporting initiative (GRI); Monetary accounting. 


\section{Introduction}

Despite the growing importance of sustainable accounting aspects from diverse angles in the literature (Burritt \& Schaltegger, 2010; Chousa \& Castro, 2006; Jones, 2010; Lamberton, 2005; Mook, 2006; Perrini \& Tencati, 2006; Schaltegger \& Wagner, 2006; Taplin, Bent, \& Aeron-Thomas, 2006), as well as the incremental interest in adopting sustainable accounting tools (Bebbington, 2007; Dreyer, Hauschild, \& Schierbeck, 2006; Frame \& Cavanagh, 2009; Gauthier, 2005; Schaltegger, Hörisch, \& Harms, 2012) by organisations, no comprehensive, reliable and objective accounting mechanism has been developed until now to monetise CSR impacts. There are very few trial studies that monetise the non-monetary impacts of some environmental and social aspects. However, those trials are either from an economic angle (Figge \& Hahn, 2004, 2005; Figge \& Schaltegger, 2000) or use a non-comprehensive subjective accounting approach (Bebbington, Brown, \& Frame, 2007; Frame \& Cavanagh, 2009) at project/product level. Meanwhile, there is a lack of research focusing on social accounting aspects in general (Deegan \& Soltys, 2007; Tinker \& Gray, 2003), and a shortage of social quantitative impacts compared with qualitative description by firms in particular (Deegan \& Rankin, 1996), despite those aspects being of significant concern to stakeholders. As a consequence, sustainable accounting information appears to be inaccurate and unsatisfactory when employing CSR information to support management decisions or to report sustainable development performance disclosures to stakeholders. Therefore, companies are unable to create better business opportunities by differentiating themselves in the marketplace as sustainable growth organisations that are capable of creating stakeholders' and shareholders' value.

Additionally, it is not clear from the literature what the full range of appropriate detailed drivers of a comprehensive system are, although sustainable accounting systems could assist companies to deal with environmental and social aspects (Schaltegger et al., 2012). Based on the literature, some - but not all_ of the CSR-decision drivers have been identified by theoretical frameworks developed that build on the concept of sustainable, social and/or environmental accounting (Bebbington, 2007; Castro \& Chousa, 2006; Frame \& Cavanagh, 2009; Lamberton, 2005; Perrini \& Tencati, 2006; Richmond, Mook, \& Quarter, 2003; Schaltegger \& Wagner, 2006; Taplin et al., 2006). Furthermore, incorporation of a full range of CSR-decision drivers, including corporate governance, environment and social drivers together, into accounting systems is not widely handled by the literature and, to date, there has not been a full attempt at monetising those drivers (Bebbington et al., 2007; Frame \& Cavanagh, 2009). Apparently, companies have a lack of expertise and limited awareness regarding the key role of sustainability accounting concepts in providing an integrated comprehensive system to overcome these problems and create values (Perrini \& Tencati, 2006; Wall \& Greiling, 2011).

Therefore, previous reasons are aligned together to motivate this paper to develop and introduce a conceptual design of a CSR monetary accounting impact mechanism for sustainable organisations1. The mechanism designed by this paper seeks to contribute to both

${ }^{1}$ Sustainable organisations are usually concerned with the long-term development of economic, environmental and social performance to assure their continuing existence. Subsequently, companies adopt sustainable accounting practices to meet 


\section{Mll Macrothink}

International Journal of Accounting and Financial Reporting

ISSN 2162-3082

2016, Vol. 6, No. 2

practice and the literature, as it is expected to provide companies with an integrated comprehensive system to gauge and enhance the CSR performance and stakeholders' engagement. The mechanism could meet/satisfy most of the companies' stakeholders' needs, concerns and demands, as well as internal decision-making needs and external reporting requirements.

This paper's objective is to develop and introduce a conceptual model design to monetise corporate CSR performance impacts. For the purpose of the paper, the scope of sustainable accounting systems primarily involves developing a monetary accounting conceptual model by extending those systems to monetise corporate governance, environmental and social performance impacts through integrating the effect of stakeholders' pressures and public information needs on management decisions and accounting information generated. To do so, the paper will cover the following sections; literature to present the background to the problem importance and addresses for research gap, then an intensive discusses for model assumptions and the most appropriate theories and accounting terminologies to support the designed model followed by a depict and description of the proposed mechanism. Finally, conclusion combined with implications/ contributions will be presented.

\section{Literature Review}

The growing volume of literature dedicated to sustainable accountancy and decision-making reflects clearly the growing interest among academics in these issues (Bebbington et al., 2007; Birkin, Edwards, \& Woodward, 2005; Gray, 1992; Lamberton, 2005; Schaltegger \& Burritt, 2006; Taplin et al., 2006). This is complemented by the increasing awareness of organisations about the importance of sustainable business practices and their impact either on CSR or financial performance, as well as on company and stakeholder value created (Artiach, Lee, Nelson, \& Walker, 2010; Attig, Cleary, Ghoul, \& Guedhami, 2013; Dhaliwal, Radhakrishnan, Tsang, \& Yang, 2012; El Ghoul, Guedhami, Kwok, \& Mishra, 2011; Guney \& Schilke, 2010; Platt, Demirkan, \& Platt, 2010; Rausch, 2011; Roberts \& Mahoney, 2004; Shum et al., 2009; Surroca \& Tribó, 2008). Sustainable business practices are generally based on the business life cycle performance, which is a tool used to assess the business sustainable development and by using sustainable accounting systems as the main generators of accounting information.

Although sustainable accounting systems have been promoted as an important alternative approach in overcoming the shortcomings of traditional accounting systems, majority of the sustainable accounting systems adopt full cost accounting approach to monetise mainly the environmental impact without a comprehensive coverage for social impact (Antheaume, 2004; Bebbington et al., 2007; Bebbington \& Larrinaga, 2014; Frame \& Cavanagh, 2009; Herbohn, 2005). Therefore, there is a need to develop more comprehensive sustainable accounting systems that actually are able to generate a wider range of useful monetary

sustainability targets (Lamberton, 2005) and as a valuable business strategy to create a sustainable organisation in the marketplace. By successfully creating a positive reputation as green producers or service providers and the perception of being socially aware organisations, companies can create better relationships with their stakeholders (Shum, Chen, \& Burritt, 2009) and benefit by creating long-term profit and adding value as sustainable organisations (Choi \& Wang, 2009). In this regard, sustainable organisations aim at managing and measuring their CSR impacts in monetary terms while creating value to satisfy their stakeholders in relation to these impacts (Bebbington, 2007; Castro \& Chousa, 2006). 


\section{Mll Macrothink}

International Journal of Accounting and Financial Reporting

ISSN 2162-3082 2016, Vol. 6, No. 2

sustainable accounting information for decision-makers. As well, those systems should be able to overcome the lack of social accounting information (Luke, 2016) and push further to integrate social aspects into a comprehensive sustainable accounting system that is able to generate meaningful and understandable information about social impacts, as well as environmental and financial impacts.

On the other hand, there are several calls, recently, have been made to flag the importance and the need for monetising the environmental and social non-monetary impacts such as biodiversity (Atkins, Gräbsch, \& Jones, 2014), climate change (Atkins, Atkins, Thomson, \& Maroun, 2015) and social value (Retolaza, San-Jose, \& Ruíz-Roqueñi, 2016) for organisations, accounting and finance discourse to providing stakeholders with a comprehensive picture of an organisation's performance. (Atkins et al., 2015; Integrated Reporting Committee of South Africa (IRC), 2011). The main motivation behind these calls is the lack of integration between financial and non-financial metrics in corporate reporting, even by the largest companies either releasing sustainability or integrated reports. In addition, some studies confirm that there is no actual internalisation of looming environmental and social crises in organisations' risk assessment and business sustainability (Intergovernmental Panel on Climate Change (IPCC), 2013; Retolaza et al., 2016).

Furthermore, to improve the outcome of the decision-making process, Gasparatos, El-Haram and Horner (2009) suggested the adoption of a diverse set of metrics to assess sustainability, coupled with stakeholder involvement. They emphasised the unavailability of a single sustainability metric that can assess sustainability in a comprehensive way (Gasparatos et al., 2009). Furthermore, Gray (2006) indicated that sustainability accounting should incorporate improvements in external disclosures for environmental and social reporting to create shareholder value for sustainable organisations. On the other hand, Adams and LarrinagaGonzález (2007) concluded that sustainability accounting and reporting literature has largely ignored practice within organisations. They argued that further engagement in research with organisations might reduce negative sustainability impacts and improve their sustainability performance.

Correa and Larrinaga (2015) investigated such research engagement in social and environmental accounting across 32 articles publishing engagement research studies. They found diverse issues in engagement research with organizations that practice sustainability accounting and accountability, particularly relevant to lack of stakeholder engagement and paucity in organizations' driven characteristics that to be considered in the decision about the locus of engagement research. On the other side, recent increases in CSR reporting and auditing practice indicate the increased awareness of firms about the importance of being accountable to all stakeholders at every stage (Belal, 2002), using reporting as an instrument for promoting stakeholder accountability (Cooper \& Hopper, 2007). Although this is compatible with distinctive features of AccountAbility 1000 (2008) and GRI (2010; 2011), firms have different motivations to undertake stakeholders' reporting, such as improving their economic performance (Roberts \& Mahoney, 2004) or contributing to the citizenship perspective and treating stakeholders in a morally acceptable manner (Wall \& Greiling, 2011). 


\section{Mll Macrothink}

International Journal of Accounting and Financial Reporting

ISSN 2162-3082 2016, Vol. 6, No. 2

Further, the reporting literature indicates that companies are socially responsible and engage in 'profit-maximising' sustainability because they contemplate a return from sustainability activities (McWilliams \& Siegel, 2001; Shum et al., 2009). Recently, Free Cash Flow (FCF) has become an important figure for both stakeholders and shareholders (Figge \& Hahn, 2005; Figge \& Schaltegger, 2000), as well as a measure of financial capacity, like profitability (Artiach et al., 2010). Arif and Hartnett (2005) emphasised that a diverse range of possible and unique wealth outcomes are provided to companies and their shareholders by FCF generation. Therefore, for engagement purpose, to meet stakeholders' demands and achieve a higher level of CSR performance, management needs to make operational, investment and finance decisions to create the FCF (Chousa \& Castro, 2006) that will be available for further CSR expenditures, projects and investments.

On the other hand, commonly, very large amounts of slack resources (free cash flow) may lead to managers' relaxation and inefficiency by wasting excess resources and reducing the search for risky or innovative projects (Zona, 2012), which leads to agency conflict and an increase in their costs. However, Surroca and Trib'o (2008) emphasised that internal corporate governance mechanisms have a positive moderating role in controlling the connection between management discretion decisions and expensive CSR activities. Thus corporate governance has been covered by the comprehensive CSR-decision drivers, for the first time in the literature, adopted by the suggested mechanism to mitigate/ prevent irresponsible management decisions in allocating excess resources expenditures to CSR activities, which thus affect a firm's financial performance.

Finally, business sectors have used sustainability reporting as a means of maintaining their favoured position in controlling capital or scarce resources (Deegan, 2007; Deegan, Cooper, \& Shelly, 2006). Kolk (2003) criticised the sustainability reports that have been used as a public relations tool without demonstrating sustainability performance with enough quantifiable data, either monetary or non-monetary, as they have mainly focused on enhancing the corporate image via providing the company's policies and sustainability issues. To overcome this weakness, Shum et al. (2009) suggested identifying the driving forces of sustainability reporting first, that is, the factors that influence the company's decision to prepare a sustainability report. On the other hand, Dhaliwal et al. (2012) argued that analysts of firms' financial performance can get benefits from information disclosed about the mechanisms adopted by firms to handle issues related to stakeholders in their CSR disclosure. Therefore the mechanism focuses on stakeholders' demands to demonstrate a conceptual model for building a monetary value using FCF for corporate sustainability performance.

Based on the prior literature, it is purported that there was no comprehensive model identified that contains the necessary sustainability drivers and accounting concepts for a proposed mechanism. Sustainability accounting as a significant accounting approach had been promoted in the literature from various points of view (Lamberton, 2005; Schaltegger \& Burritt, 2010; Schaltegger et al., 2012; Taplin et al., 2006) that can be adopted by organisations to help make internal and external decisions regarding mainly environmental and social impact (costs/revenue or negative/positive) measurement and management. However, until now, no accounting study has provided a comprehensive model to monetise 


\section{NI Macrothink}

International Journal of Accounting and Financial Reporting

ISSN 2162-3082 2016, Vol. 6, No. 2

non-monetary impacts of either social, environmental or corporate governance. Furthermore, there are several calls to develop sustainability accounting practices for sustainable organisations to be able to measure an integrated and comprehensive value created for the company and its stakeholders (Cheng, Ioannou, \& Serafeim, 2014; Figge \& Hahn, 2004; Gibbon \& Dey, 2011; Gray, 2006; Wall \& Greiling, 2011).

In an attempt to have steps towards CSR monetary measurement, mainly from a stakeholders' perspective, this paper objective is to develop and introduce a conceptual model for a CSR monetary accounting impact mechanism, which would combine environmental accounting and social accounting with traditional accounting to help in the monetising and measurement of CSR impacts.

\section{Design of suggested mechanism: Theoretical Bases and Accounting Concepts}

\subsection{Elements of conceptual model}

The model's elements are presented in figure 1 to guide the development of the conceptual model. First, it identifies stakeholders' pressures/needs as sustainability/CSR-decision (nonmonetary) drivers. Secondly, it sets out the types of management decisions that will be affected by stakeholders/CSR-decision drivers. Third, it identifies the range of monetary accounting information that have been affected by management decisions. From this monetary accounting information generated by sustainable accounting systems, it considers the monetary value for each CSR impact and the question whether the organization is creating/destroying its stakeholders' value. The assumption underlying this (using the FCF as a comprehensive monetary measure) is that stakeholder drives management decision and, therefore, company value.
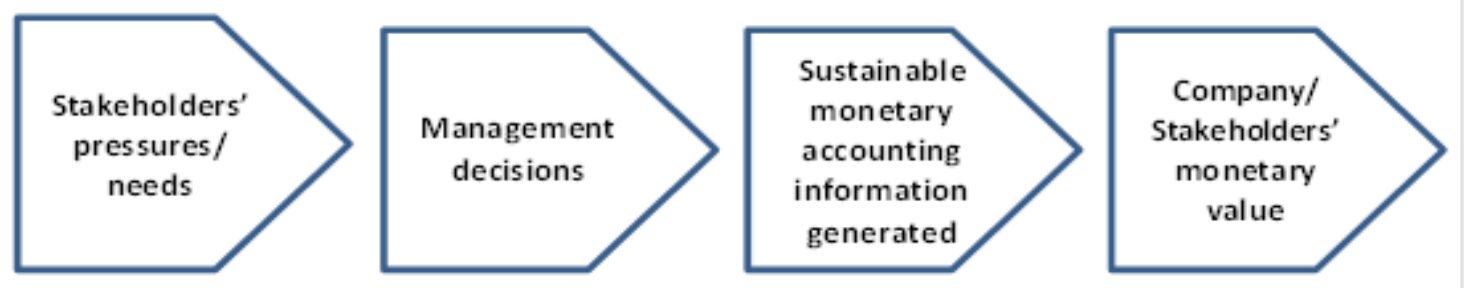

\section{Figure 1: Elements of conceptual model}

3.1.1. Stakeholders' pressures/needs as sustainability/CSR-decision drivers.

As stakeholders are the main source of all corporate resources, companies tended to use sustainability reporting as a means of maintaining good relationships with key stakeholders. Maintaining good relationships with stakeholders leads to more effective use of a firm's resources, while enhancing profit and creating organisational value (Benson \& Davidson, 2010; Berman, Wicks, Kotha, \& Jones, 1999). Stakeholders who are supplying critical resources or can affect the achievement of the firm's objectives are considered legitimate and should be involved in the decision-making process due to their powerful effect upon the 


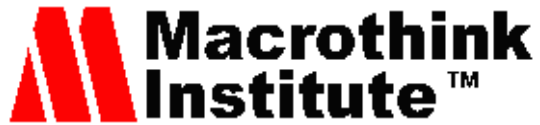

International Journal of Accounting and Financial Reporting

ISSN 2162-3082 2016, Vol. 6, No. 2

continued viability of the company (Artiach et al., 2010; Deegan \& Blomquist, 2006; Rausch, 2011). As a result, stakeholders as system drivers have the capacity to affect corporate resources and legitimate continuing existence; therefore, their desired information should be incorporated into disclosures in both financial and non-financial forms. To handle this issue, companies need to engage more deeply with their stakeholders' needs in order to improve their sustainability performance (Adams \& Larrinaga-González, 2007). Consequently, the system that incorporates wider stakeholders' interests can present companies with a way to create more comprehensive financial and non-financial/monetary and non-monetary information, not only to improve business decision-making, but also to create stakeholder value.

\section{P1: the higher the stakeholders' pressures, the more likely to be engaged and to affect management decisions.}

Significantly, CSR-decision drivers of suggested mechanism are defined in this conceptual model as covering the full range of stakeholders' needs, concerns and demands that could be fully captured from external and internal organisations (Bebbington, Gray, Hibbitt, \& Kirk, 2002; Deegan \& Blomquist, 2006), including corporate governance, environmental and social (employees and community) aspects. Consequently, the conceptual model defines system drivers using sustainable, environmental, social and traditional accounting concepts to capture information needed to match stakeholders' interests that are identified based on GRI (GRI, 2011) requirements as a benchmark for stakeholders' interests and demands, in addition to corporate governance for the first time.

\subsubsection{Management decisions}

Companies experience growing pressure by stakeholders. These pressures arise mainly from environmental/social regulations, as well as public demand for greater social responsibility. For example, activities with adverse environmental impacts can carry considerable financial implications for corporations, as regulators turn to market-based economic instruments to impose legal liability for environmental damage (Gray \& Bebbington, 2001). Therefore, corporate decision-makers seem increasingly under pressure to consider and report the wider environmental and social impacts of their companies' activities as a response to their stakeholders' pressures and needs.

Managers who are able to respond more effectively and efficiently to CSR initiatives and stakeholders' pressures are also more likely to achieve better performance (Erhemjamts, Li, \& Venkateswaran, 2012), and management of stakeholders is a good way of improving financial results. However, the difficulty in reconciling the demands of a wide set of stakeholders has been emphasised in corporate governance literature (Jensen, 2001; Tirole, 2001). Cooper and Owen (2007) and Belal (2002) found that it is important to establish a far more pluralistic form of corporate governance. Without this governance as a precondition for effective stakeholder accountability, Cooper and Owen (2007) argue that information disclosure will only have a very limited decision-influencing effect at the management level, while Surroca and Tribó (2008) claim that if there are efficient internal corporate governance mechanisms, stakeholders and managers would be natural allies. Also, maintaining good 


\section{MInstitute ${ }^{\text {Mit }}$ Macrothink}

International Journal of Accounting and Financial Reporting ISSN 2162-3082

relationships with key stakeholders creates an organisational resource that leads to more effective use of a firm's resources (Berman et al., 1999) and higher firm value (Benson \& Davidson, 2010). Additionally, Surroca and Tribó (2008) emphasise that internal corporate governance mechanisms have a positive moderating role in controlling the connection between management discretion decisions and expensive CSR activities. Therefore, the conceptual model considers corporate governance as one of the CSR drivers in the monetary mechanism, which has an important effect on the rationality of management decisions, as well as, one of stakeholders' needs/demand to avoid/reduce agency problem.

P2: the higher the stakeholders' influence upon management decisions, the more the significant to consider corporate governance to maximise management decisions rationality.

Wall and Greiling (2011) and Chousa and Castro (2006) identified three types of management decisions (operational, investment and finance) and seven items that serve as independent variables for forecasting free cash flows. However, managers are supposed to influence these items by their decisions to enhance FCF value (Chousa \& Castro, 2006). These items are operating profit margin, sales growth rate, cash tax rate, working capital needs, fixed capital needs, costs of capital and value growth duration (Wall \& Greiling, 2011). Thus, following Wall and Greiling (2011) and Chousa and Castro (2006), the integration of these items within management decisions (operational, investment and finance) increase or decrease FCF value. Further, Surroca and Tribó (2008) indicated a negative relationship between corporate governance mechanisms and excess resources (FCF) expenditures allocated to CSR activities, as well as irresponsible management decisions.

\subsubsection{Sustainable monetary accounting information generated}

Stakeholders usually prefer looking for companies' performance in money values as understandable, measurable and meaningful indicators of companies' activities and value created (Figge \& Schaltegger, 2000; Wall \& Greiling, 2011). However, companies' current sustainability accounting practices are still unable to provide monetary measures for several CSR impacts related to corporate governance, environmental and social activities (mainly physical and descriptive) to improve internal decision-making and to meet stakeholders' needs. To deal with this matter, sustainability accounting could be developed by the extension of traditional accounting practice (Lamberton, 2005; Schaltegger \& Burritt, 2010) to monetise the non-monetary impacts of environmental, social and corporate governance performance impacts. Therefore, sustainability accounting could be developed as a comprehensive accounting system that captures stakeholders' interests and reports a full range of monetary information according to the stakeholders' perspective.

P3: integrated sustainable accounting systems are capable to generate a comprehensive monetary accounting measure for corporate CSR impacts that reflect management decisions.

The conceptual model has considered sustainability accounting practice as existing accounting systems (environmental, social and traditional) that provide companies with a way 


\section{MInstitute Mach $^{m}$}

International Journal of Accounting and Financial Reporting

ISSN 2162-3082 2016, Vol. 6, No. 2

to accurately and reliably capture, measure and generate/report corporate governance, environmental and social impact information. Sustainability accounting practice is recognised as a measurement tool to provide a full range of accounting information to enhance management decision-making and financial disclosures. Additionally, sustainability accounting practice defined by this model means to provide corporate social responsibility (CSR) reporting to add value to sustainable organisations.

Accounting systems (environmental, social and traditional) in the conceptual model will be responsible about generating the sustainable accounting information required to monetise CSR impact, which reflect management decisions (i.e. FCF), in addition to other accounting information that measure the economic impact. FCF, as a comprehensive monetary accounting measure for stakeholders (Figge \& Hahn, 2005; Figge \& Schaltegger, 2000), is equal to the integrated value of the seven items (operating profit margin, sales growth rate, cash tax rate, working capital needs, fixed capital needs, costs of capital and value growth duration) that be influenced by the three types of management decisions; operational, investment and finance, but after excluding shareholders' interests such as dividends. While, economic monetary impact in the conceptual model, suggested to be adopted from Pava and Krausz (1996), to cover three comprehensive groups of measures; firstly, accounting measures that contain the majority of company information that indicates how the historical record has been influenced by prior governance, social and environmental decisions and performance. Secondly, market measures that provide future-oriented measures reflect estimates about the net present value of the expected impact of current decisions/practices on future earnings. Finally, risk measures reflect the riskiness of cash flow produced through operational, investment and finance activities. It is notable that the majority of prior empirical studies used these measures separately to investigate the link between CSR and corporate financial performance (such as ROA and FCF) without considering their joint effect.

\subsubsection{Company/Stakeholders' monetary value}

Sustainable organisations need to create value not only in economic performance but also in environmental, social and corporate governance performance. Consequently, a sustainable organisation is a 'growth' organisation concerned with the development of sustainability in relation to environmental, social, economic and corporate governance (Joseph, 2012). Thus, a sustainable company is significantly involved in the development of CSR performance, as well as economic performance. However, creating value is the consequence of the combined effort of diverse stakeholders who together form the cooperating team. Therefore, created value represents wealth for a larger group of stakeholders (Mook, Richmond, \& Quarter, 2003) and a successful relationship with stakeholders ensures that a company's sustainability is achieved (Bebbington, 2007).

P4: the higher the monetary value allocated for corporate CSR performance due to stakeholders' pressures/engagements, the better the total monetary value created.

\subsection{Theoretical perspective}

The model fuses two theories under the umbrella of positive accounting theory: stakeholder 


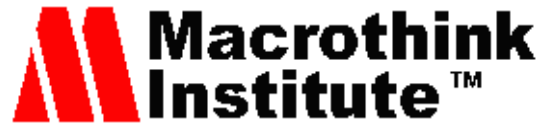

International Journal of Accounting and Financial Reporting

ISSN 2162-3082

2016, Vol. 6, No. 2

theory and prospect decision theory. They would be used to depict the relationship between the level of adoption of legal and ethical obligations relating to stakeholders' concerns/needs in providing information (Cooper \& Owen, 2007; Schaltegger \& Figge, 2000; Van der Laan, Adhikari, \& Tondkar, 2005) relating to CSR impacts on free cash flow (FCF). FCF would be used as a new comprehensive unique measure of sustainability from the stakeholders' perspective.

Freeman (2007) and Freeman, Harrison and Wicks (2007) explained that not only do companies affect stakeholders, but stakeholders can also affect companies. In simple terms, stakeholder groups supply companies with 'contributions' and they have the expectation of being rewarded with some sort of 'inducements'. The stakeholder view, as an all-inclusive broader approach, tries to accommodate the diversity of involvements and motivations, while shareholder agency theory is postulated with wealth-related arguments in favour of a certain class of stakeholders (Rausch, 2011). The evaluative norm chosen by shareholder agency theory to assess organisational activities is the unique criterion of economic efficiency exposed in the language of profit, while stakeholder theory considers justice distribution, where an ethics-related criterion is tied up with the basic economic efficiency criterion to address the multiplicity of a large number of corporate participants' motivations in an organisational coalition (Harrison, Bosse, \& Phillips, 2010; Mallik \& Mitra, 2009; Roberts \& Mahoney, 2004; Wall \& Greiling, 2011).

Practically, the continued existence and viability of the company is dependent on the availability of critical resources. Therefore, the higher the stakeholders' control level upon critical resources, the more powerful the stakeholders are in imposing their needs, interests and claims (Artiach et al., 2010; Deegan et al., 2006). Those stakeholders with power and legitimacy are more able to activate their claims upon the company (Deegan \& Blomquist, 2006; Rausch, 2011). Although there are a variety of rights, claims or interests of powerful legitimate participants (Freeman et al., 2007), it ends up with a simple measure like 'profit' for the favourite shareholders alone, which is recognised as a unique measure of a company's efforts and achievements (Pava \& Krausz, 1996). Therefore, profit as a narrow measure of the free-market mechanism and ethical neutrality (which is widely known in the accounting literature as 'agency theory') is a complete mismatch as an analysis framework for the motivations of modern organisations (Mallik \& Mitra, 2009). This refers to the inability of accounting as a social science to face and take into consideration modern society's relevant and distinct problems.

Thus, in the design of a monetising mechanism (see figure 2 at the end of this section), to determine and cover the key needs, concerns, pressures and objectives of stakeholders' legal legitimate obligations and ethical ones in measuring social and environmental impacts, stakeholder theory will be employed to help in highlighting theoretically those obligations, pressures, objectives, needs and concerns from stakeholder perspectives. These pressures and concerns could be translated practically by following GRI requirements, which, in turn, are incorporated as system sustainability drivers (governance, environment, social including employees and community) into the theoretical/conceptual model and are required to be monetised for both reporting and further internal decision-making. By doing so, more 
monetary information would be created to support governance, social and environmental internal decision-making, as well as provide more useful and measurable (for non-measurable impact) information for external disclosures.

While prospect decision theory was introduced by Kahneman and Tversky (1979) and assumes that possible losses are overweighed compared to possible gains (Sambrook, Roser, \& Goslin, 2012). One of the key predictions of this theory is that "decision-makers' perceptions are biased, implying an asymmetry in how they judge losses versus gains" (Van der Laan, Van Ees, \& Van Witteloostuijn, 2008, p. 300). Following this logic, the effect on corporate financial performance of bad corporate environmental and social performance can be expected to be larger than the impact of good corporate environmental and social performance (Guney \& Schilke, 2010). This is because decision-makers evaluate the investment decisions related to environmental and social performance more heavily in a situation in which they stand to lose legitimacy for being a good corporate citizen than in a situation where the company has satisfactory or good legitimacy relationships with its stakeholders2. Therefore, in this paper's context, it is argued that the higher the stakeholders' pressure, that is, the risk of losing legitimacy (measured by CSR), the better the management decisions taken (measured by FCF).

As corporations deal with a wide range of stakeholders to maintain or gain legitimacy, it is argued that stakeholders (other than shareholders) are capable of affecting the course of a business and resources in the long and short-run (Rausch, 2011; Van der Laan et al., 2008). For example, interest groups can influence the corporations' attractiveness to prospective investors (Richardson \& Welker, 2001) or employees (Greening \& Turban, 2000), as well as the customers' buying decisions (Chen, 2009). Consequently, this will motivate managers to build good relationships with stakeholders to maximise their value created and reduce managers' utility problem, that is, 'minimising utility losses' (Wall \& Greiling, 2011). Therefore, they avoid losing continuity of existence due to not complying with regulations or not providing satisfactory responses and actions to other stakeholders' needs and pressures. On the other hand, the responsiveness of corporations to various stakeholders' claims depends upon the way in which managers perceive the business environment (Jawahar \& McLaughlin, 2001; Van der Laan et al., 2008). For example, a firm may seek to improve its reputation in the eyes of environmental NGOs or local citizens by investing in an advertising campaign or in local community schools to emphasise its good environmental policies. By doing so, firms tries to avoid legal procedures, for example, that could stop site expansion due to local citizens' complaints or damage due to protest campaigns by an NGO (like Greenpeace) (Van der Laan et al., 2008).

Therefore, prospect decision theory help to argue that there is a relationship between corporate environmental and social performance disclosed due to stakeholder groups' pressures (sustainability drivers) and free cash flow (FCF) as a comprehensive corporate financial monetary measure that reflects all the different management decisions taken during the year, including operation, investment and finance decisions.

\footnotetext{
${ }^{2}$ Usually during stable and booming economic situations (Palmer \& Wiseman, 1999).
} 


\subsection{Accounting perspective}

Accounting systems are playing a reflective measuring role of adopted management decisions in the company and translate the updates or changes in those decisions. Accounting systems reflect the influence of decisions taken on the company's performance from different perspectives, concepts and measures adopted under each accounting system (traditional, environmental and social).

Where profitability is the main daily concern within the context of a corporation, accounting as a set of information systems (financial and management) is a strong behavioural driver for management decisions (Volosin, 2008). Nowadays there is more focus on stakeholders' concerns (corporate governance, environmental and social), so, they need to be included within these traditional accounting systems. By doing so, linking stakeholders' concerns with everyday decision-making will be more likely to occur. Additionally, the understanding by accounting practitioners of the necessity of linking environmental and social data to traditional accounting systems and the incremental adoption of sustainability reporting principles/guidelines (such as GRI) to meet the variety of stakeholders' concerns has favoured the birth of environmental and social accounting as subsets of the broader accounting systems.

On one hand, environmental accounting is responsible for generating the environmental accounting information (monetary and physical) in the form of environmental/sustainability reports that meet the stakeholders' needs and requirements. It includes both physical flow accounting which provides information about the physical environmental impacts, such as materials, energy, water, wastes and emissions (Burnett \& Hansen, 2008; Jasch, 2009; Schaltegger \& Burritt, 2000) and environmental cost accounting which provides information on the environmental costs, earning and savings (monetary units) associated with these impacts (IFAC 2005; Schaltegger \& Burritt, 2000). Environmental costs are usually included within other company overhead costs in the financial statements to reach the figures of profit and net cash flow. Furthermore, to facilitate the reduction of environmental harmful/negative impacts and related costs, as well as to respond to the social, political and economic pressures surrounding the use of natural resources, the measurement of environmental impacts would be very helpful (Burnett \& Hansen, 2008). In addition, this measurement is necessary for successful development and operation of an accurate environmental management system (EMS) (Environmental Agency Japan (EAJ), 2000). However, some environmental impacts are still difficult to measure in monetary terms, while others are disclosed in a descriptive way due to their nature and the difficulty of being measured in physical units.

On the other hand, social accounting is responsible for generating the social accounting information (monetary and physical) in the form of sustainability/CSR reports that meet the stakeholders' concerns and expectations. In contrast to the wide variety of environmental accounting tools and mechanisms adopted, social accounting tools and mechanisms are limited and not commonly developed theoretically and methodologically (Mook, 2014; Parker, 2005). According to Richmond, Mook and Quarter (2003), the use of qualitative data and descriptive statistics are widely involved in the application of social accounting to assess 


\section{Ml Macrothink \\ International Journal of Accounting and Financial Reporting \\ ISSN 2162-3082 \\ 2016, Vol. 6, No. 2}

organisations in meeting their stakeholders' expectations. Therefore, social measures are still under-researched and not easy to quantify. Generally, Maas and Bouma (2004) divided social measures into two types and both types can influence corporate financial performance. They are internal measures, such as safety and health care, education and training, job satisfaction levels and employee retention, and external measures, such as volunteer work, sponsoring, involvement of stakeholders and investment in society. A research conducted by Spence (2009) suggested that the social accounting area requires further studies incorporating organisations' social impacts into their performance and value process. Additionally, Gray (2002) indicated that combining environmental and social issues could be employed for improving accounting's approach to stakeholder concerns. Incorporating social accounting into an integrated comprehensive accounting framework would assist companies to become more environmentally and socially aware organisations and to enhance the sustainability of organisations (Gray, 2002; Mook et al., 2003).

Therefore, the traditional, environmental and social accounting systems are the corner-stones of the monetising mechanism model that are responsible for generating the key monetary accounting information for economic impact and CSR impact (see figure 2). FCF is a core financial monetary measure for stakeholders' value creation, as Figge and Hahn (2005) mention that the usual indicator used for companies' value created in the financial markets is profit or the free cash flow figure. "By contrast to profit, which is interpreted as the wealth created for owners or shareholders, value added represents the wealth for a larger group of stakeholders" (Mook et al., 2003, p. 285). 


\section{I Macrothink \\ International Journal of Accounting and Financial Reporting \\ ISSN 2162-3082 \\ 2016, Vol. 6, No. 2}

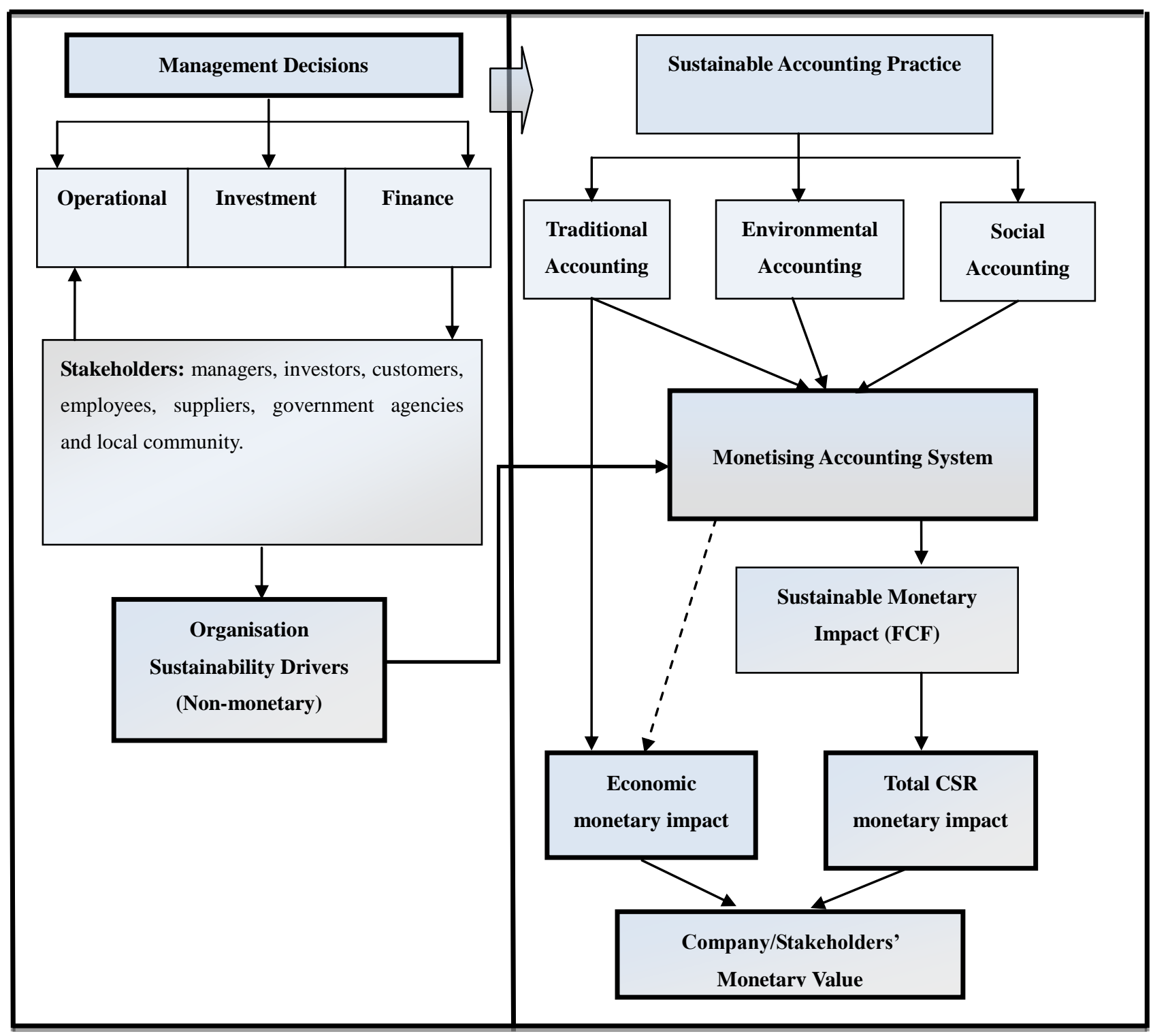

Figure 2: A theoretical framework for a monetising mechanism model

\section{Discussion of proposed Model: CSR monetary accounting impact mechanism}

To represent stakeholders' needs/ concerns/ pressures/ demands, either environmentally or socially, into management decisions, management need to be motivated to gain further benefits or to be threatened by losing legitimacy and continuity of existence and therefore losing their jobs. Prospect decision theory explains managerial risk preferences and indicates that management can be risk averse when facing decisions as gains and be risk seeking when facing decisions as losses (Van der Laan et al., 2008; Zona, 2012). Therefore, management responses to the possibility of losses are overweighed compared to possible gains (Sambrook et al., 2012). Thus, investment decisions related to environmental and social performance are evaluated differently by decision-makers in a situation in which they stand to lose legitimacy for not being a good corporate citizen compared with a situation where the company has a satisfactory or good legitimacy relationship with its stakeholders. Therefore, stakeholders are capable of affecting the course of a business, management decisions and resources in the long 
and short run (Rausch, 2011; Van der Laan et al., 2008) by employing higher pressure and indicating the risk of losing legitimacy and continuity.

To incorporate stakeholders' pressures, needs and concerns into management decisions, companies need to develop and employ strategies and policies that support and enhance the adoption of stakeholders' engagement and sustainability values. To do so, companies need to adopt effective corporate governance mechanisms to incorporate stakeholders' demands into the decision-making process, because the board of directors significantly shapes management decisions in general and management decisions towards risk in particular (Boyd, Haynes, \& Zona, 2011). Therefore, corporate governance drivers have been adopted into the model to reflect corporate sustainable strategies, plans and mechanisms to engage with stakeholders and to avoid the possibility of losing legitimacy or breaching law regulations regarding CSR requirements (Surroca \& Tribó, 2008).

Further, stakeholder theory indicates that adopting all stakeholders' interests into decisionmaking process would help companies to develop economic performance as well as environmental and social efficiency and stakeholders' satisfaction (Freeman et al., 2007; IFAC, 2005). While the literature about the relationship between CSR and financial information indicates that measuring of information based on logical cause and effect relationship would lead to more reliable and understandable logical measurement (Carr \& Gratton, 2013; Castro \& Chousa, 2006; Guney \& Schilke, 2010). Thus, the effect of CSRdecision drivers on management decisions and therefore on information generated by accounting systems, would result in a more reliable and understandable logical accounting measure such free cash flow to monetise CSR impacts. Free cash flow is an integrated measure for generated information from accounting systems that reflects management decisions; such as sales growth, operating profit margin and cash tax rate which are affected by operational decisions, while, working capital and fixed capital needs which are determined by investment decisions, and finally, costs of capital and value growth duration which are influenced by finance decisions. Therefore, free cash flow is a comprehensive measure of sustainability from stakeholders' perspective, as well as an accounting base measure for stakeholders' value creation (Figge \& Hahn, 2005).

Based on prior discussion, there is a chance to allocate free cash flow among the CSRdecision drivers that have contributed in generating the free cash flow amount and therefore monetise the impact of each CSR driver based on its share in the free cash flow generated; by adopting the following elementary formula: Total CSR monetary value $=f_{1} \mathrm{FCF}+f_{2} \mathrm{FCF}+$ $f_{3} \mathrm{FCF}$. Where $f$ is CSR (environment, social, and governance) drivers' function/contributed share in FCF.

However, this proposed allocation wouldn't be realistic without considering that CSRdecision drivers could reflect competing/conflicting stakeholders' needs/pressures, as well as, complimentary/cooperative claims (Neville \& Menguc, 2006). Therefore, each stakeholder group is trying to attract management attention to allocate more resources and efforts to meet this group's needs upon other stakeholders' groups account. Thus the relationship between CSR-decision drivers and FCF should be a reverse relationship which is matching with 


\section{Ml Macrothink}

International Journal of Accounting and Financial Reporting

ISSN 2162-3082

2016, Vol. 6, No. 2

Surroca and Tribó (2008) argument about the important role of corporate governance mechanism in controlling the connection between management discretion decisions and expensive CSR activities. That implies a negative relationship between corporate governance mechanisms and excess resources (FCF) expenditures allocated to CSR activities, as well as irresponsible management decisions. Therefore, the adjusted elementary formula is: Total $\mathrm{CSR}$ monetary value $=1 / f_{1} \mathrm{FCF}+1 / f_{2} \mathrm{FCF}+1 / f_{3} \mathrm{FCF}$. Where $1 / f$ is the reverse absolute value of CSR (environment, social, and governance) drivers' function/contributed share in FCF.

To conclude, the higher the stakeholder impact, the more the management focuses on CSR issues to not lose legitimacy. Therefore, the more the CSR expenditure and investments, the lower the FCF amount left over. For example, an increase in company investment on employee training programs due to union pressures leads to a decrease in FCF available to other stakeholders (Yu, 2012). Thus, generally, companies with higher CSR driver score for specific stakeholders' group and lower FCF are more sustainable from this beneficiary stakeholders' point of view. A lower FCF level is preferable as well from the shareholders' point of view; however, the main difference between shareholders and other stakeholders is the usage or investment direction of this FCF, based on the strength of pressure of each group and on corporate strategies and objectives.

Furthermore, in practice, companies provide disclosures on their CSR performance activities to create mainly shareholders' value translated into profitability measures as an ultimate goal achievement (Pava \& Krausz, 1996). However, companies do not clarify to what extent the CSR activities exactly contribute to the shareholders' values directly and indirectly. Conceptual model helps various stakeholders to identify and measure their value created directly from corporate CSR practices (share/contribution in FCF measure) or indirectly via economic corporate value created as a whole (traditional financial performance measures) by adopting the following elementary formula: Total stakeholders' value created= Total CSR monetary value + Total Economic value. Therefore, the model adopted free cash flow as the best integrated and comprehensive monetary accounting measure from stakeholders' point of view that incorporates and translates all CSR activities information and related decisions taken to monetise CSR impacts and its related value created.

\section{Conclusion}

Although the incremental calls and needs to monetise CSR impacts in the literature and practice, studies in CSR and sustainable accounting have not provided us with integrated and objective models to measure and monetise the CSR impacts of organisations' activities and their stakeholders' engagement effect on CSR-decisions. In this context, CSR monetary accounting impact mechanism conceptual model has been introduced and developed based on an integrated sustainability accounting approach that mainly built upon the sustainable accounting systems to generate a comprehensive accounting measure (free cash flow), which is a reflection of management decisions and stakeholders' needs.

Theoretically, the monetary conceptual model is expected to make contributions to the literature through expanding sustainable organisation practice, and incorporating the sustainability accounting concepts (environmental, social and traditional) to generate 
monetary impact measures for CSR performance. Further, the developed mechanism would appropriately identify CSR-decision drivers from stakeholders' perspectives more accurately, comparably and comprehensively because the model adopts the GRI requirements to identify the commonly important needs and concerns of stakeholders. However; the mechanism could be replicated by adopting other guidelines or even individually by each company based on its stakeholders' needs and expectations map. Additionally, extending the sustainable accounting practice by enabling management decisions' interaction with both stakeholders' demands on the one hand and accounting information on the other is seen by many authors as a significant contribution to the literature.

Practically, an effective monetising system of sustainability accounting is needed to facilitate the measurement of corporate governance, environmental and social impacts generated by organisations' activities; where the majority of them are still expressed in non-monetary units. The conceptual model is expected to enhance stakeholders' engagement and to provide companies with a basic guidance/tool to externally report their environmental, social and corporate governance impacts in an understandable monetary form in addition to their financial/ economic impacts to stakeholders. Finally, the model offers the further advantages of providing useful monetary information and easy interpretation for CSR monetary impacts measurement to stakeholders and the companies concerned. It is applicable to any context in which companies are committed to develop stakeholder engagement processes and intend to gauge CSR monetary performance.

\section{References}

AccountAbility. (2008). AA 1000: AccountAbility principle standards 2008. London, UK: AccountAbility.

Adams, C.A., and Larrinaga-González, C. (2007). "Engaging with organisations in pursuit of improved sustainability accounting and performance". Accounting, Auditing and Accountability Journal 20(3): 333-355.

Antheaume, N. (2004). "Valuing external costs. From theory to practice: implications for full cost environmental accounting". European Accounting Review 13(3): 443-464.

Arif, M., and Hartnett, N. (2005). "Free cash flow return regularities.". Journal of the Financial Services Institute of Australasia (JASSA) 4(1): 6-12.

Artiach, T., Lee, D., Nelson, D., and Walker, J. (2010). "The determinants of corporate sustainability performance". Accounting and Finance 50(1): 31-51.

Atkins, J., Atkins, B.C., Thomson, I., and Maroun, W. (2015). "'Good" news from nowhere: imagining utopian sustainable accounting". Accounting, Auditing \& Accountability Journal 28(5): 651-670.

Atkins, J., Gräbsch, C., and Jones, M.J. (2014). "Biodiversity reporting: exploring its anthropocentric nature". In M. Jones (Ed.), Accounting for Biodiversity (pp. 215-245). 
Abingdon, Oxon: Routledge.

Attig, N., Cleary, S.W., Ghoul, S., and Guedhami, O. (2013). "Corporate legitimacy and investment: Cash flow sensitivity". Journal of Business Ethics 114(2): 1-18.

Bebbington, J. (Ed.). (2007). Accounting for sustainable development performance. London, UK: Elsevier Ltd.

Bebbington, J., Brown, J., and Frame, B. (2007). "Accounting technologies and sustainability assessment models". Ecological Economics 61(2-3): 224-236.

Bebbington, J., Gray, R., Hibbitt, C., and Kirk, E. (2002). Full cost accounting: Principles and practices. London, UK: The Association of Chartered Certified Accountants (ACCA).

Bebbington, J., and Larrinaga, C. (2014). "Accounting and sustainable development: an exploration". Accounting, Organizations and Society 39(6): 395-413.

Belal, A.R. (2002). "Stakeholder accountability or stakeholder management: A review of UK firms' social and ethical accounting, auditing and reporting (SEAAR) practices". Corporate Social Responsibility and Environmental Management 9(1): 8-25.

Benson, B.W., and Davidson, W.N. (2010). "The relation between stakeholder management, firm value, and CEO compensation: A test of enlightened value maximization". Financial Management 39(3): 929-964.

Berman, S., Wicks, A., Kotha, S., and Jones, T. (1999). "Does stakeholder orientation matter? The relationship between stakeholder management models and firm financial performance". Academy of Management Journal 42(5): 488-506.

Birkin, F., Edwards, P., and Woodward, D. (2005). "Accounting's contribution to a conscious cultural evolution: An end to sustainable development.". Critical Perspectives on Accounting 16(3): 185-208.

Boyd, B.K., Haynes, K.T., and Zona, F. (2011). "Dimensions of CEO-board relations". Journal of Management Studies 48(8): 1892-1923.

Burnett, R.D., and Hansen, D.R. (2008). "Ecoefficiency: Defining a role for environmental cost management". Accounting, Organizations and Society 33(6): 551-581.

Burritt, R.L., and Schaltegger, S. (2010). "Sustainability accounting and reporting: Fad or trend?". Accounting, Auditing and Accountability Journal 23(7): 829-846.

Carr, L.P., and Gratton, S. (2013). "Scorecard sustainability: Discovering the inflection point for business scorecard termination or major alteration". Journal of Corporate Accounting and Finance 24(3): 25-37.

Castro, N.R., and Chousa, J.P. (2006). "An integrated framework for the financial analysis of sustainability". Business Strategy and the Environment 15(5): 322-333.

Chen, C.X. (2009). "Who really matters? Revenue implications of stakeholder satisfaction in a health insurance company". The Accounting Review 84(6): 1781-1804. 


\section{Ml Macrothink}

International Journal of Accounting and Financial Reporting

ISSN 2162-3082

2016, Vol. 6, No. 2

Cheng, B., Ioannou, I., and Serafeim, G. (2014). "Corporate social responsibility and access to finance". Strategic Management Journal 35(1): 1-23.

Choi, J., and Wang, H. (2009). "Stakeholder relations and the persistence of corporate financial performance". Strategic Management Journal 30(8): 895-907.

Chousa, J.P., and Castro, N.R. (2006). "Integrating sustainability into traditional financial analysis". In S. Schaltegger, M. Bennett ,R. Burritt (Eds.), Sustainability accounting and reporting (pp. 83-108). Dordrecht, The Netherlands: Springer Netherlands.

Cooper, D.J., and Hopper, T. (Eds.). (2007). Critical theorising in management accounting research. Amsterdam: Elsevier Ltd.

Cooper, S.M., and Owen, D.L. (2007). "Corporate social reporting and stakeholder accountability: The missing link". Accounting, Organization and Society 32(7-8): 649-667.

Correa, C., and Larrinaga, C. (2015). "Engagement research in social and environmental accounting". Sustainability Accounting, Management and Policy Journal 6(1): 5-28.

Deegan, C. (2007). Australian financial accounting (5 ${ }^{\text {th }}$ ed.). North Ryde, NSW, Australia: McGraw Hill.

Deegan, C., and Blomquist, C. (2006). "Stakeholders' influence on corporate reporting: An exploration of the interaction between WWWF-Australia and Australian minerals industry". Accounting Organization and Society 31(4-5): 343-372.

Deegan, C., Cooper, B., and Shelly, M. (2006). "An investigation of TBL report assurance statements: UK and European evidence". Managerial Auditing Journal 21(4): 329-371.

Deegan, C., and Rankin, M. (1996). "Do Australian companies report environmental news objectively?: An analysis of environmental disclosures by firms prosecuted successfully by the Environmental Protection Authority". Accounting, Auditing and Accountability Journal 9(2): 50-67.

Deegan, C., and Soltys, S. (2007). "Social accounting research: An Australasian perspective". Accounting Forum 31(1): 73-89.

Dhaliwal, D.S., Radhakrishnan, S., Tsang, A., and Yang, Y.G. (2012). "Nonfinancial disclosure and analyst forecast accuracy: International evidence on corporate social responsibility disclosure". The Accounting Review 87(3): 723-759.

Dreyer, L.C., Hauschild, M.Z., and Schierbeck, J. (2006). "A framework for social life cycle impact assessment.". International Journal of Life Cycle Assessment 11(2): 88-97.

El Ghoul, S., Guedhami, O., Kwok, C.C., and Mishra, D. (2011). "Does corporate social responsibility affect the cost of capital?". Journal of Banking and Finance 35(9): 2388-2406.

Environmental Agency Japan (EAJ). (2000). Developing an environmental accounting system: Year 2000 report. Japan: Environmental Agency Japan.

Erhemjamts, O., Li, Q., and Venkateswaran, A. (2012). "Corporate social responsibility and 
its impact on firms' investment policy, organizational structure and performance". Journal of Business Ethics 111(2): 1-18.

Figge, F., and Hahn, T. (2004). "Sustainable value added: Measuring corporate contributions to sustainability beyond eco-efficiency". Ecological Economics 48(2): 173-187.

Figge, F., and Hahn, T. (2005). "The cost of sustainability capital and the creation of sustainable value by companies". Journal of Industrial Ecology 9(4): 47-58.

Figge, F., and Schaltegger, S. (2000). What is 'stakeholder value'? Developing a catchphrase into a benchmarking tool. Lueneburg, Germany: University of Lueneburg and Bank Pictet in association with United Nation Environment Programme (UNEP).

Frame, B., and Cavanagh, J. (2009). "Experiences of sustainability assessment: An awkward adolescence". Accounting Forum 33(3): 195-208.

Freeman, R.E. (2007). "The development of stakeholder theory: An idiosyncratic approach". In K.J. Smith ,M.A. Hitt (Eds.), Great minds in management: The process of theory development (pp. 418-435). New York, USA: Oxford University Press.

Freeman, R.E., Harrison, J.S., and Wicks, A.C. (2007). Managing for stakeholders: Survival, reputation, and success. New Haven, CT, USA: Yale University Press.

Gasparatos, A., El-Haram, M., and Horner, M. (2009). "The argument against a reductionist approach for measuring sustainable development performance and the need for methodological pluralism". Accounting Forum 33: 245-256.

Gauthier, C. (2005). "Measuring corporate social and environmental performance: The extended life-cycle assessment". Journal of Business Ethics 59(1-2): 199-206.

Gibbon, J., and Dey, C. (2011). "Developments in social impact measurement in the third sector: Scaling up or dumbing down?". Social and Environmental Accountability Journal 31(1): 63-72.

Global Reporting Initative (GRI). (2010, 26-28 May 2010). "2010 GRI global conference executive brief.". Paper presented at the The Amsterdam Global Conference on Sustainability and Transparency., Amsterdam, The Netherlands.

Global Reporting Initiative (GRI). (2011). The G3.1 sustainability reporting guidelines. Amsterdam, The Netherlands: Global Reporting Initiative.

Gray, R. (1992). "Accounting and environmentalism: An exploration of the challenge of gently accounting for accountability, transparency and sustainability". Accounting, Organizations and Society 17(5): 399-425.

Gray, R. (2002). "The social accounting project and accounting organizations and society privileging engagement, imaginings, new accountings and pragmatism over critique?". Accounting, Organizations and Society 27(7): 687-708.

Gray, R. (2006). "Social, environmental and sustainability reporting and organizational value 
creation? Whose value? Whose creation?". Accounting, Auditing and Accountability Journal 19(6): 793-819.

Gray, R., and Bebbington, J. (2001). Accounting for the environment ( $2^{\text {nd }}$ ed.). London, UK: SAGE Publications.

Greening, D.W., and Turban, D.B. (2000). "Corporate social performance as a competitive advantage in attracting a quality workforce". Business and Society 39(3): 254-280.

Guney, Y., and Schilke, A. (2010). The relationship between corporate social and financial performance: Do endogeneity, non-linearity and adjustment issues matter? UK: University of Hull.

Harrison, J., Bosse, D., and Phillips, R. (2010). "Managing for stakeholders, stakeholder utility function and competitive advantage". Strategic Management Journal 31(1): 58-74.

Herbohn, K. (2005). "A full cost environmental accounting experiment.". Accounting Organizations and Society 30(6): 519-536.

Integrated Reporting Committee of South Africa (IRC). (2011). Framework for integrated reporting and the integrated report: available at: www.sustainabilitysa.org (accessed 5 June 2012).

Intergovernmental Panel on Climate Change (IPCC). (2013). Climate change 2013: the physical science basis.: available at: www.ipcc.ch/report/ar5/wg1/ (accessed 1 June 2015).

International Federation of Accountants (IFAC). (2005). International guidance document: Environmental management accounting-exposure draft. USA: International Federation of Accountants.

Jasch, C. (2009). Environmental and material flow cost accounting: Principles and procedures. Vienna, Austria: Springer Science and Business Media B. V.

Jawahar, I.M., and McLaughlin, G.L. (2001). "Toward a descriptive stakeholder theory: An organizational life cycle approach". Academy of Management Review 26: 397-414.

Jensen, M. (2001). "Value maximization, stakeholder theory, and the corporate objective function". Journal of Applied Corporate Finance 14: 8-21.

Jones, M.J. (2010). "Accounting for the environment: Towards a theoretical perspective for environmental accounting and reporting". Accounting Forum 34(2): 123-138.

Joseph, G. (2012). "Ambiguous but tethered: An accounting basis for sustainability reporting". Critical Perspectives on Accounting 23(2): 93-106.

Kahneman, D., and Tversky, A. (1979). "Prospect theory: An analysis of decisions under risk". Econometrica 47(2): 263-291.

Kolk, A. (2003). "Trends in sustainability reporting by the Fortune Global 250". Business Strategy and the Environment 12(5): 279-291. 


\section{Ml Macrothink}

International Journal of Accounting and Financial Reporting

ISSN 2162-3082

2016, Vol. 6, No. 2

Lamberton, G. (2005). "Sustainability accounting: A brief history and conceptual framework". Accounting Forum 29(1): 7-26.

Luke, B. (2016). "Measuring and reporting on social performance: From numbers and narratives to a useful reporting framework for social enterprises". Social and Environmental Accountability Journal 36(2): 103-123.

Maas, K., and Bouma, J. (2004). "Social added-value of CSR from a welfare economic perspective". Paper presented at the Conference Towards a Practical Research (Social) Responsibility Agenda, Gent, Belgium.

Mallik, A.K., and Mitra, S. (2009). "Accounting and accountability: A stakeholder-agent perspective". The IUP Journal of Accounting Research and Audit Practices 8(3-4): 7-19.

McWilliams, A., and Siegel, D. (2001). "Corporate social responsibility: A theory of the firm perspective". Academy of Management Review 26(1): 117-127.

Mook, L. (2006). "Integrating and reporting an organisation's economic, social and environmental performance: The expanded value added statement". In S. Schaltegger, M. Bennett ,R. Burritt (Eds.), Sustainability accounting and reporting (pp. 281-298). Dordrecht, The Netherlands: Springer Netherlands.

Mook, L. (2014). "An Integrated Social Accounting Model for Nonprofit Organizations". In E. Costa, L.D. Parker ,M. Andreaus (Eds.), Accountability and Social Accounting for Social and Non-Profit Organizations, Advances in Public Interest Accounting (Vol. 17, pp. 197221): Emerald Group Publishing Limited.

Mook, L., Richmond, B.J., and Quarter, J. (2003). "Integrated social accounting for nonprofits: A case from Canada". International Journal of Voluntary and Nonprofit Organizations 14(3): 283-297.

Neville, B.A., and Menguc, B. (2006). "Stakeholder Multiplicity: Toward an Understanding of the Interactions between Stakeholders". Journal of Business Ethics 66(4): 377-391.

Palmer, T.B., and Wiseman, R.M. (1999). "Decoupling risk taking from income stream uncertainty: A holistic model of risk". Strategic Management Journal 20(11): 1037-1062.

Parker, L.D. (2005). "Social and environmental accountability research: A view from the commentary box". Accounting, Auditing and Accountability Journal 18(6): 842-860.

Pava, M.L., and Krausz, J. (1996). "The association between corporate social-responsibility and financial performance: The paradox of social cost". Journal of Business Ethics 15(3): 321-357.

Perrini, F., and Tencati, A. (2006). "Sustainability and stakeholder management: The need for new corporate performance evaluation and reporting systems". Business Strategy and the Environment 15(5): 296-308.

Platt, H., Demirkan, S., and Platt, M. (2010). "Free cash flow, enterprise value, and investor caution". The Journal of Private Equity 13(4): 42-50. 
Rausch, A. (2011). "Reconstruction of decision-making behaviour in shareholder and stakeholder theory: Implications for management accounting systems". Review of Managerial Science 5(2-3): 137-169.

Retolaza, J.L., San-Jose, L., and Ruíz-Roqueñi, M. (2016). "Background: Social Role of Companies and Success Indicators" Social Accounting for Sustainability: Monetizing the Social Value. (pp. 5-10): SpringerBriefs in Business.

Richardson, A., and Welker, M. (2001). "Social disclosure, financial disclosure and the cost of equity capital". Accounting, Organizations and Society 26(7-8): 597-616.

Richmond, B.J., Mook, L., and Quarter, J. (2003). "Social accounting for nonprofits: Two models". Nonprofit Management and Leadership 13(4): 308-324.

Roberts, R., and Mahoney, L.S. (2004). "Stakeholder conceptions of the corporation: Their meaning and influence in accounting research". Business Ethics Quarterly 14(3): 399-431.

Sambrook, T.D., Roser, M., and Goslin, J. (2012). "Prospect theory does not describe the feedback-related negativity value function". Psychophysiology 49 (12): 1533-1544.

Schaltegger, S., and Burritt, R. (2000). Contemporary environmental accounting: Issues, concepts and practice. Sheffield, UK: Greenleaf Publishing.

Schaltegger, S., and Burritt, R. (2006). "Corporate sustainability accounting: A catchphrase for compliant corporations or a business decision support for sustainability leaders?". In S. Schaltegger, M. Bennett ,R. Burritt (Eds.), Sustainability accounting and reporting (pp. 3759). Dordrecht, The Netherlands: Springer Netherlands.

Schaltegger, S., and Burritt, R. (2010). "Sustainability accounting for companies: Catchphrase or decision support for business leaders?". Journal of World Business 45(4): 375-384.

Schaltegger, S., and Figge, F. (2000). "Environmental shareholder value: Economic success with corporate environmental management". Eco-Management and Auditing 7(1): 29-42.

Schaltegger, S., Hörisch, J., and Harms, D. (2012, 24-26 September 2012). "Glancing into the applied tool Box: Surveying operational sustainability accounting practice". Paper presented at the $15^{\text {th }}$ EMAN Conference on Environmental and Sustainability Management Accounting in collaboration with the CSEAR International Congress on Social and Environmental Accounting Research, Helsinki, Finland.

Schaltegger, S., and Wagner, M. (2006). "Managing sustainability performance measurement and reporting in an integrated manner: Sustainability accounting as the link between the sustainability balanced scorecard and sustainability reporting". In S. Schaltegger, M. Bennett ,R. Burritt (Eds.), Sustainability accounting and reporting (pp. 681-697). Dordrecht, The Netherlands: Springer Netherlands.

Shum, P., Chen, H., and Burritt, R.L. (2009, 27-28 July 2009). "A cross-country study of the determinants of sustainability reporting and assurance". Paper presented at the $1^{\text {st }}$ South 


\section{Macrothink}

International Journal of Accounting and Financial Reporting

ISSN 2162-3082

2016, Vol. 6, No. 2

American Congress on Social and Environmental Accounting Research (CSEAR), Brasil.

Spence, C. (2009). "Social accounting's emancipatory potential: A Gramscian critique". Critical Perspectives on Accounting 20(2): 205-227.

Surroca, J., and Tribó, J.A. (2008). "Managerial entrenchment and corporate social performance". Journal of Business Finance and Accounting 35(5-6): 748-789.

Taplin, J.R.D., Bent, D., and Aeron-Thomas, D. (2006). "Developing a sustainability accounting framework to inform strategic business decisions: A case study from the chemicals industry". Business Strategy and the Environment 15(5): 347-360.

Tinker, T., and Gray, R. (2003). "Beyond a critique of pure reason: From policy to politics to praxis in environmental and social research". Accounting, Auditing, and Accountability Journal 16(5): 727-761.

Tirole, J. (2001). "Corporate governance". Econometrica 69(1): 1-35.

Van der Laan, G., Van Ees, H., and Van Witteloostuijn, A. (2008). "Corporate social and financial performance: An extended stakeholder theory, and empirical test with accounting measures". Journal of Business Ethics 79(3): 299-310.

Van der Laan, S.J., Adhikari, A., and Tondkar, R.H. (2005). "Exploring differences in social disclosures internationally: A stakeholder perspective". Journal of Accounting and Public Policy 24 (2): 123-151.

Volosin, E. (2008). Environmental accounting: Issues in management accounting. Munich, Germany: GRIN Publishing.

Wall, F., and Greiling, D. (2011). "Accounting information for managerial decision-making in shareholder management versus stakeholder management". Review of Managerial Science 5(2-3): 91-135.

Yu, B. (2012). "Agency costs of stakeholders and capital structure: International evidence". Managerial Finance 38(3): 303-324.

Zona, F. (2012). "Corporate investing as a response to economic downturn: Prospect theory, the behavioural agency model and the role of financial slack". British Journal of Management 23(S1): S42-S57.

\section{Copyright Disclaimer}

Copyright for this article is retained by the author(s), with first publication rights granted to the journal.

This is an open-access article distributed under the terms and conditions of the Creative Commons Attribution license (http://creativecommons.org/licenses/by/3.0/). 